\title{
Observations on Foraging and New Prey Records for the Amazon Treeboa (Corallus hortulanus, Squamata: Boidae)
}

\author{
Pedro da Costa Silva ${ }^{1}$, Robert W. Henderson ${ }^{2}$, Antonio Alvares Tavares ${ }^{3}$, \\ Sâmia Caroline Melo Araújo ${ }^{4}$, Anderson Guzzi \\ Photographs by the senior author. \\ ${ }^{1}$ Núcleo de Pesquisa em Biodiversidade e Biotecnologia, (BIOTEC), Campus Ministro Reis Velloso, (CMRV). \\ Universidade Federal do Piauí, UFPI, Parnaíba, Piauí, Brazil \\ ${ }^{2}$ Milwaukee Public Museum, Milwaukee, Wisconsin 53233 USA (henderson@mpm.edu) \\ ${ }^{3}$ Universidade Federal do Piauí, Campus Ministro Reis Velloso, Laboratório de Zoologia, Parnaíba, Piauí, Brazil \\ ${ }^{4}$ Granduanda em Ciências Biológicas pela Universidade Estadual do Piauí-UESPI, CEP 64280-000 Campo Maior, Piauí, Brazil \\ ${ }^{5}$ Universidade Federal do Piauí, Campus Ministo Reis Velloso, Laboratório de Zoologia, Parnaíba, Piauí, Brazil
}

$\mathrm{D}$ espite their relative abundance in many Neotropical lowland snake faunas and the frequency with which they are often encountered, observations on foraging and predation in species of the boid genus Corallus are extremely rare. Henderson (2002) witnessed only one $C$. grenadensis feeding during 700-800 encounters with the species, and he missed the actual prey capture. More recently, Yorks et al. (2003) and Henderson et al. (2007) have witnessed prey captures by $C$. grenadensis and C. cookii, respectively. Here we present detailed observations on foraging and prey capture by the geographically and ecologically widespread Amazon Treeboa, Corallus hortulanus (Linnaeus), as well as new records of prey species for $C$. hortulanus.

Observations were made on Batatas Island, Piauí, Brazil. The island represents a small portion of Parnaíba Delta, mea-

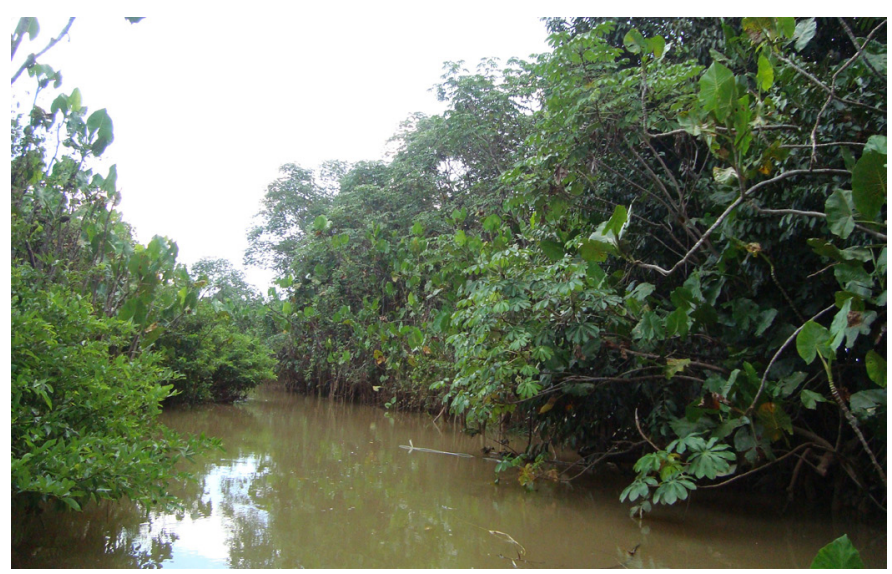

Fig. 1. A section of Igarapé dos Camaleões on Batatas Island, Piauí, Brazil. suring $15 \mathrm{~km}^{2}$, bordered to the west by the Rio Parnaíba and to the east by Lontras and Mirim creeks. Most of the land is devoted to agriculture, rice in the region that comprises gallery forest and sugarcane and banana plantations in the interior. During May and July 2012, surveys were made for Corallus hortulanus during the lunar phases (new moon, first quarter, full moon, and last quarter) between $1745 \mathrm{~h}$ and 0540 $\mathrm{h}$ along a creek known by locals as Igarapé dos Camaleões (Fig. 1). The length of the entire creek is $3 \mathrm{~km}$, but only 1.5 $\mathrm{km}$ were accessible by canoe. An infrared monocular (Yukon Nightfall) and a video camera with night vision capability (Sony CCD-TRV138) were used to record treeboa behavior. Sixty-four observations on $C$. hortulanus were made over a period of 288 hours.

During moonlit nights between $1800 \mathrm{~h}$ and $0034 \mathrm{~h}, 29$ observations were recorded: 23 boas $(79.3 \%)$ were moving on branches, one was suspended by its tail, one captured an iguana, one captured a bird, and three were coiled with their heads facing down (Fig. 2). During moonless nights between $1800 \mathrm{~h}$ and $0145 \mathrm{~h}, 35$ observations were made: 21 boas were moving on branches $(60 \%), 12$ were coiled with head facing down (34.3\%), one was observed during the shedding process, and one was hanging by its tail, possibly fishing ( $\mathrm{da}$ Costa Silva and Henderson 2010). The ambient temperature ranged between $28{ }^{\circ} \mathrm{C}$ and $25^{\circ} \mathrm{C}$ during the hours of $1750-2350 \mathrm{~h}$ (the time span during which most snakes were observed).

On 18 July 2012, an adult C. hortulanus (approximately $1.20 \mathrm{~m}$ total length) was observed about $2.3 \mathrm{~m}$ from a group of six Great Ani (Chrotophaga major) that were sleeping 


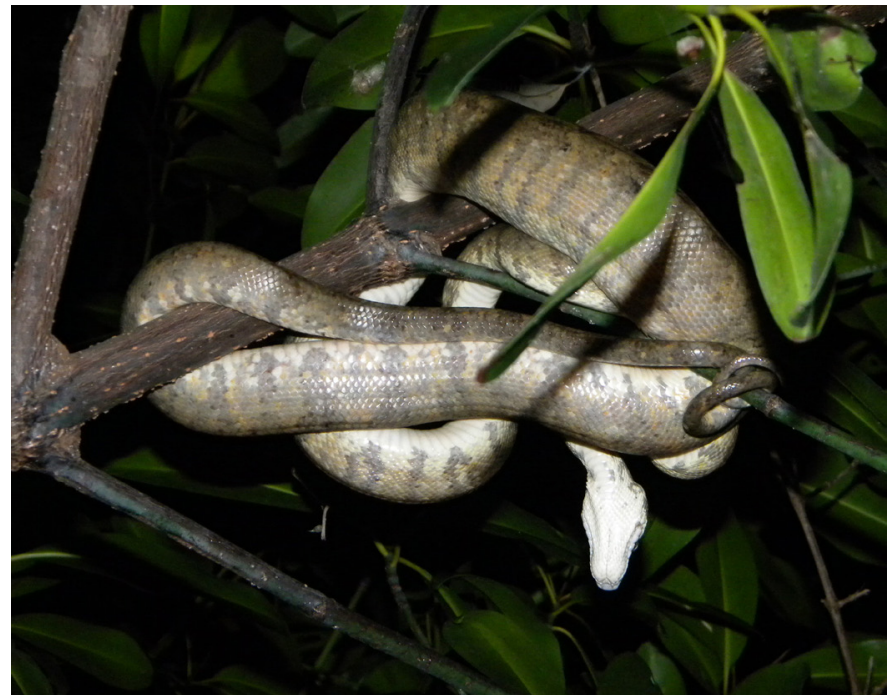

Fig. 2. Corallus hortulanus in a resting posture along Igarapé dos Camaleôes.

or resting on the branches of a thorn-laden tree (Macherium lunatum). The head of the boa was oriented directly toward the birds and it flicked its tongue three times. Over a span of $10 \mathrm{~min}$, the boa moved toward the birds, approaching slowly and flicking its tongue several times. When the distance between the snake and the nearest bird was about $80 \mathrm{~cm}$, all of the birds flew away.

On 4 June 2012 (full moon), the distress call of a bird was heard at $1905 \mathrm{~h}$ and we observed a C. hortulanus (about $90 \mathrm{~cm}$ total length) that had just captured an adult Great Kiskadee (Pitangus sulphuratus, Tyrannidae) of about $17 \mathrm{~cm}$ (Fig. 3). At $1907 \mathrm{~h}$, wrapped in two of the snake's coils, the bird was still alive and attempting to escape (legs and wings thrashing, calling). A third coil was applied at $1909 \mathrm{~h}$ and at $1915 \mathrm{~h}$ the bird appeared dead. The initial attempt at swallowing began at $1919 \mathrm{~h}$ with the boa taking the bird's head in its mouth, but it appeared to be having difficulty getting beyond the bird's beak. On the third attempt at $1923 \mathrm{~h}$, it

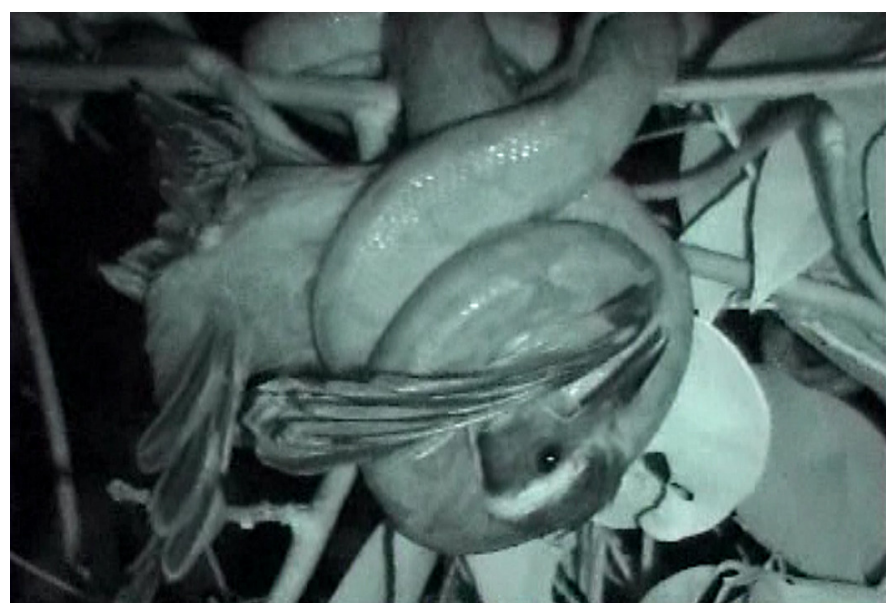

Fig. 3. Corallus hortulanus after capturing a Great Kiskadee (Pitangus sulphuratus) (image from a video).

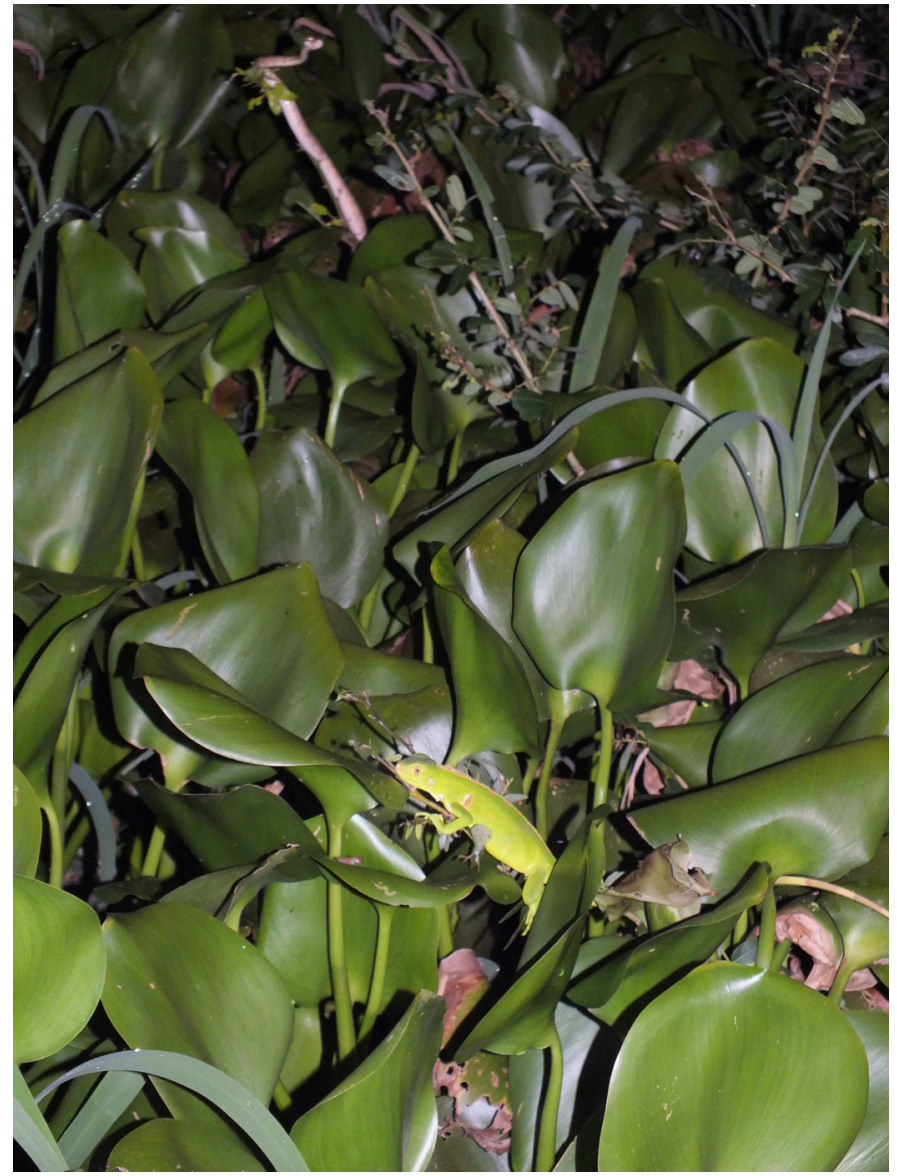

Fig. 4. Corallus hortulanus with its head elevated shortly before beginning to stalk the Iguana iguana in the foreground.

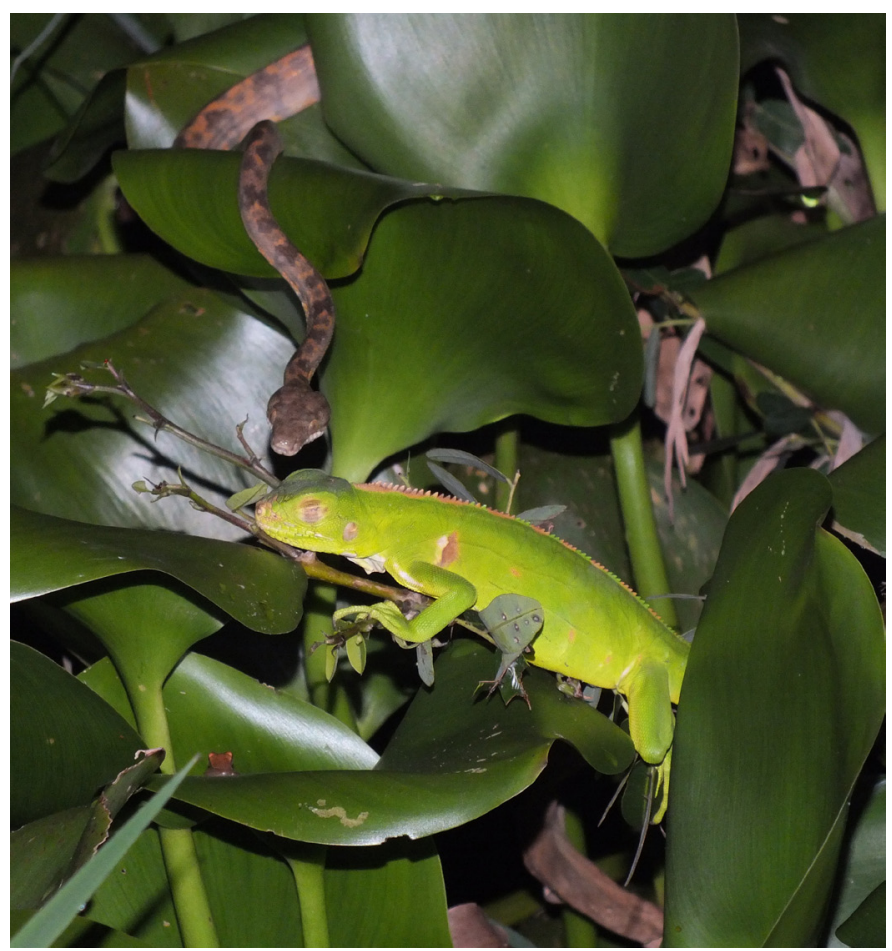

Fig. 5. Corallus hortulanus tongue-flicking at the head of the iguana just prior to capturing it. 


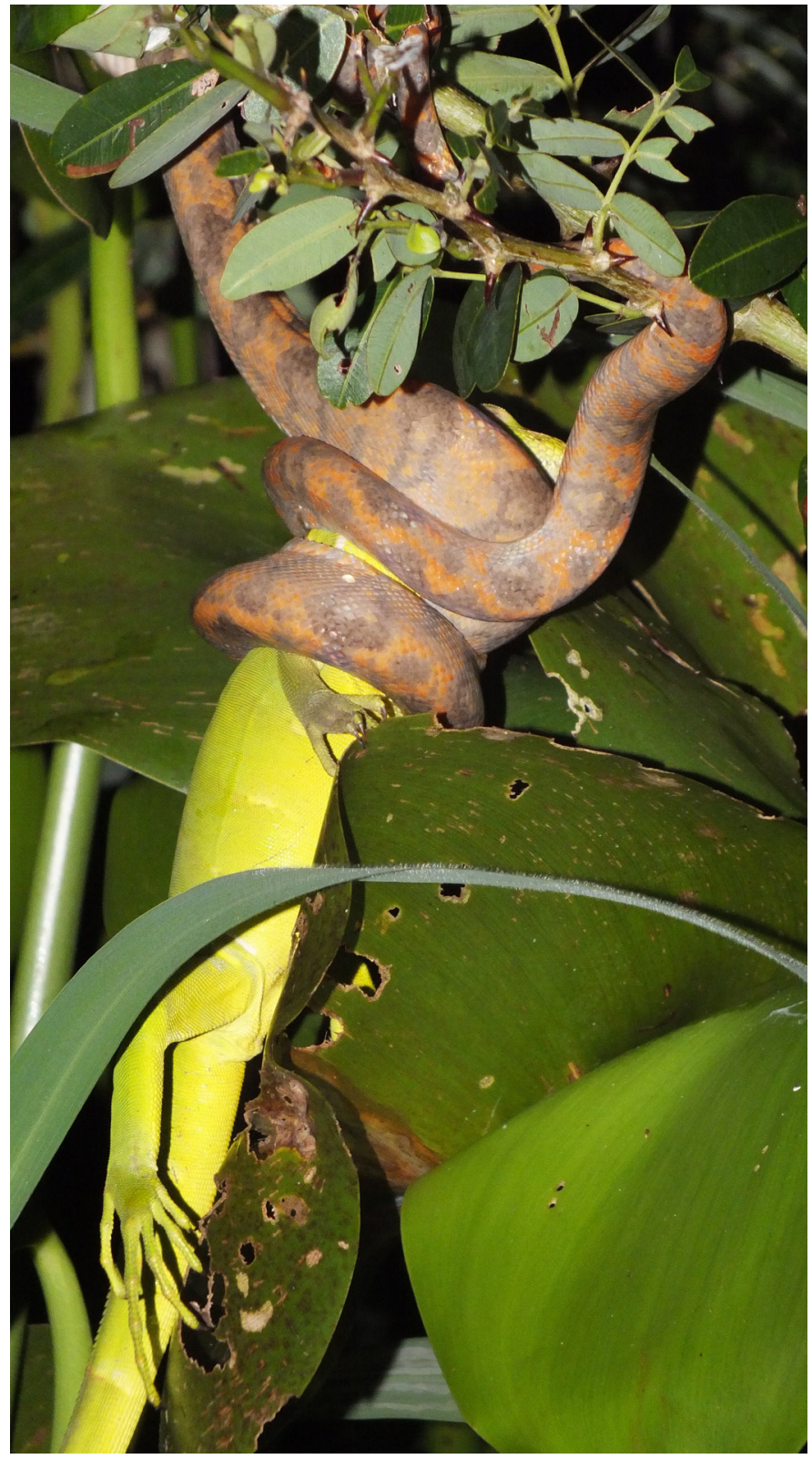

Fig. 6. Corallus hortulanus constricting the captured iguana.

was successful and deglutition was completed at $1932 \mathrm{~h}$. The snake then moved onto a branch of Montrichardia linifera along the creek and it was observed there for the next seven days.

On 2 July 2012 at 1951 h, we observed a young boa (approximately $70 \mathrm{~cm} \mathrm{SVL)} \mathrm{supported} \mathrm{on} \mathrm{Water} \mathrm{Hyacinth}$ (Eichhornia crassipes) leaves. Its head was angled upward into the air and it was flicking its tongue. A juvenile Iguana iguana (about $30 \mathrm{~cm}$ total length) was sleeping in the same Water Hyacinth colony; the distance between the boa and the iguana was at least $1.5 \mathrm{~m}$ (Fig. 4). At $1953 \mathrm{~h}$, the boa oriented its head toward the iguana and began moving. Its route to the sleeping lizard was indirect and accompanied by tongueflicking, as though trying to locate and follow a scent trail. By $2007 \mathrm{~h}$ the boa was within $30 \mathrm{~cm}$ of the iguana and at

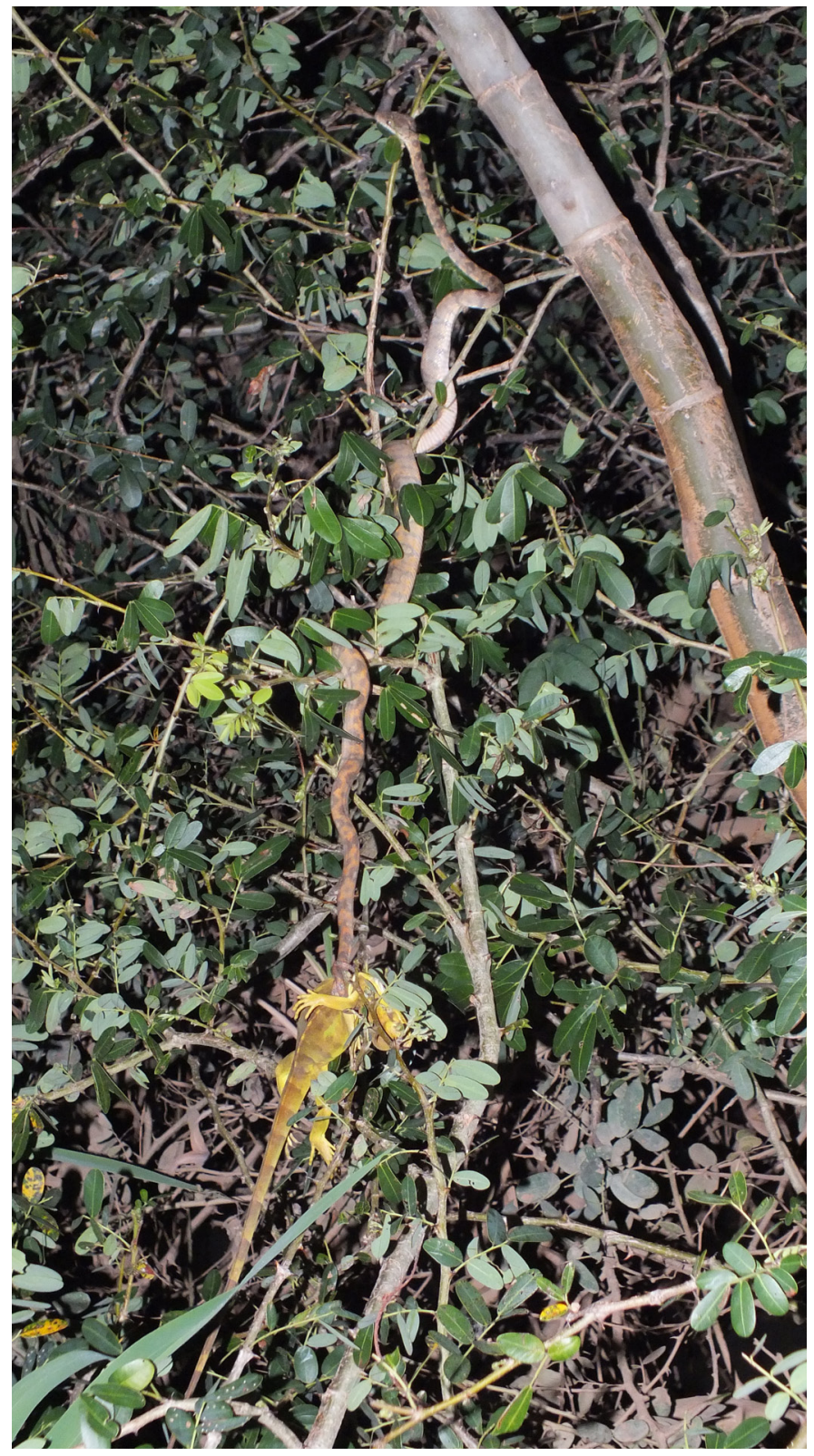

Fig. 7. Corallus hortulanus ascending with its tail wrapped around the iguana.

2011 it had approached to within $10 \mathrm{~cm}$ of the iguana's head. During 2012-2013 h the boa directed tongue flicks toward the iguana's head (Fig. 5), neck, dorsum, and tail. Finally, at $2020 \mathrm{~h}$, the boa struck the iguana on the neck and applied three coils around its body and commenced constriction (Fig. 6). The iguana whipped its tail in unsuccessful attempts to escape. By $2022 \mathrm{~h}$ the lizard appeared dead and at $2025 \mathrm{~h}$ the boa (likely aware of the presence of human observers), with the iguana in several coils of its tail, ascended about 2.5 $\mathrm{m}$ (Fig. 7). Swallowing started at $2026 \mathrm{~h}$ and was completed $19 \mathrm{~min}$ later at $2045 \mathrm{~h}$. The boa eventually moved into a tree along the creek and remained there for a period of eight days.

Birds are frequent prey of $C$. hortulanus, but lizards are not, and the Great Kiskadee and the iguana are new prey records for the species (Pizzatto et al. 2009, Henderson and Pauers 2012). 
Predation on the I. iguana provides the most interesting information. The stalking behavior parallels that of $C$. grenadensis and $C$. cookii in its incredible stealth; the snake moved $150 \mathrm{~cm}$ over a period of $27.0 \mathrm{~min}$ and the last $10 \mathrm{~cm}$ were covered in about $5.0 \mathrm{~min}$, or about $2.0 \mathrm{~cm} / \mathrm{min}$. Even when the boa had reached the sleeping lizard, it appeared to examine it from head to tail, perhaps judging where best to strike.

Most intriguing, however, is the behavior of the boa before initiating the stalking sequence that resulted in the successful capture of the iguana. What cue or cues first made it aware of the sleeping iguana? The iguana might have provided a visual cue for the boa, but based on the vegetation and the angle of the sight line from the iguana to the boa, we feel that is unlikely. Although the iguana was certainly ultimately located via substrate-based scent cues, based on Fig. 4 and other photographs not presented here, the boa might initially have became aware of the nearby potential prey based on airborne cues. If that is correct, discerning airborne information as the initial cue regarding proximate prey would preclude having to detect scent trails without a priori information that might or might not lead to appropriate prey, thus conserving valuable energy.

Acknowledgements. The senior author dedicates this note to two individuals who inspired and encouraged him in his career as a herpetologist: Prof. Roy Rosestein of the American University in Paris and Prof. José Roberto S. A Leite (BIOTEC-UFPI), who sent him to Instituto Butantan in São Paulo to study venomous snakes. He also thanks BIOTEC, Universidade Federal do Piauí in Parnaíba for logistical support and people from IB-SP, including Maria de Fatima Furtado, Carlos Jared, Francisco Luis Franco, Valdir Germano, Lora Kerb, and Dr. Sergio Henrique. Mr. Zequinha and family, especially his two sons Marcio and Marcelo, helped with fieldwork. Plant identification was provided by Ivanilza Moreira de Andrade.

\section{Literature Cited}

da Costa Silva, P. and R.W. Henderson. 2010. Observations on habitat, activity, foraging, and diet in the Amazon Treeboa, Corallus hortulanus, on Batatas Island, Parnaíba Delta, Piauí, Brazil. Reptiles \& Amphibians 17:218-221.

Henderson, R.W. 2002. Neotropical Treeboas: Natural History of the Corallus hortulanus Complex. Krieger Publishing Company, Malabar, Florida.

Henderson, R.W. and M.J. Pauers. 2012. On the diets of Neotropical treeboas (Squamata: Boidae: Corallus). South American Journal of Herpetology 7:172-180.

Henderson, R.W., M.L. Treglia, and S.D. Powell. 2007. Corallus cookii (St. Vincent Treeboa). Foraging. Herpetological Review 38:466.

Pizzatto, L., O.A.V. Marques, and K. Facure. 2009. Food habits of Brazilian boid snakes: Overview and new data, with special reference to Corallus hortulanus. Amphibia-Reptilia 30:533-544.

Yorks, D.T., K.E. Williamson, R.W. Henderson, R. Powell, and J.S. Parmerlee, Jr. 2003. Foraging behavior in the arboreal boid Corallus grenadensis. Studies on the Neotropical Fauna and Environment 38:167-172. 